$10 / 25-94950$

SANDIA REPORT

SAND93-3900 $\cdot$ UC-212

Unlimited Release

Printed December 1993

\title{
Battery Energy Storage: \\ A Preliminary Assessment of National Benefits (The Gateway Benefits Study)
}

Abbas Akhil, Hank Zaininger, Jonathan Hurwitch, Joseph Badin

Propared by

Eandla Mational Laboratorloe

Abuquerque, Now Mexico 87186 and Livermore, Callfornila 94580

for the United States Department of Enorgy

under Contract DE-ACO4-OAAL85000 
Issued by Sandia National Laboratories, operated for the United States Department of Energy by Sandia Corporation.

NOTICE: This report was prapared as an account of work sponsored by an agency of the United States Government. Neither the United States Government nor any agency thereof, nor any of their employees, nor any of their contractors, subcontractors, or their employees, makes any warranty, express or implied, or assumes any legal liability or responsibility for the accuracy, completeness, or usefulness of any information, apparatus, product, or process disclosed, or represents that its use would not infringe privately owned rights. Reference herein to any specific commercial product, process, or service by trade name, trademark, manufacturer, or otherwise, does not necessarily constitute or imply its endorsement, recommendation, or favoring by the United States Government, any agency thereof or any of their contractors or subcontractors. The views and opinions expressed herein do not necessarily state or reflect those of the United States Government, any agency thereof or any of their contractors.

Printed in the United States of America. This report has been reproduced directly from the best available copy.

Available to DOE and DOE contractors from

Office of Scientific and Technical Information

PO Box 62

Oak Ridge, TN 37831

Prices available from (615) 576-8401, FTS 626-8401

Available to the public from

National Technical Information Service

US Department of Commerce

5285 Port Royal Rd

Springfield, VA 22161

NTIS price codes

Printed copy: A03

Microfiche copy: A01 


\title{
Battery Energy Storage: A Preliminary Assessment of National Benefits (The Gateway Benefits Study)
}

\author{
Prepared By
}

\section{Utility Battery Storage Systems Program Sandia National Laboratories}

\author{
Abbas Akhil, Sandia National Laboratories \\ Hank Zaininger, Zaininger Engineering Company \\ Jonathan Hurwitch and Joseph Badin, Energetics, Inc. \\ Prepared for \\ Advanced Utility Concepts Division \\ Office of Energy Management \\ U.S. Department of Energy
}

December 1993

\begin{abstract}
Preliminary estimates of national benefits from electric utility applications of battery energy storage through the year 2010 are presented along with a discussion of the particular applications studied. The estimates in this report were based on planning information reported to DOE by electric utilities across the United States. Future studies are planned to refine these estimates as more application-specific information becomes available.
\end{abstract}




\section{Contents}

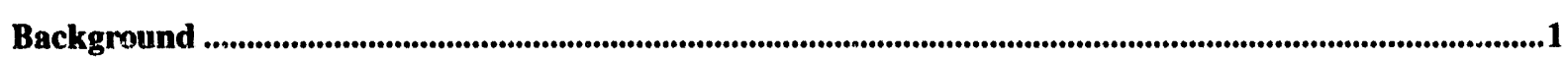

Approach/Information Sources ................................................................................................................................1

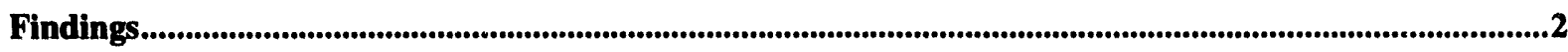

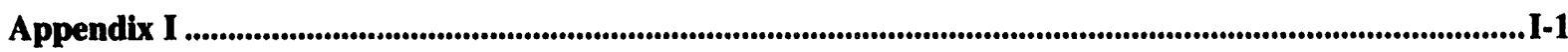

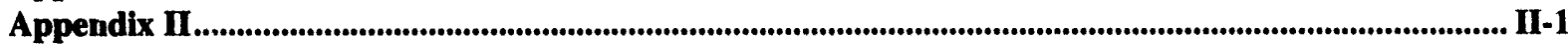

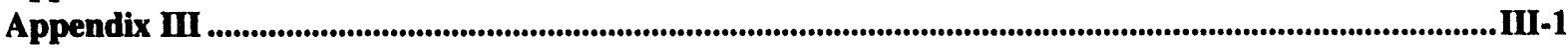

\section{Table}

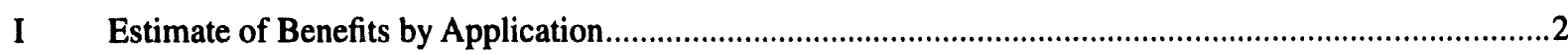




\section{Background}

Electric utilities in the U.S. are facing new challenges to preserve the complex electrical network that has until now provided reliable, inexpensive electricity to support the nation's economy. In this time of change, recognition is growing that storage could be one option to help utilities build a secure energy future. Along with this recognition, there is a gradual shift away from centralized generation to distributed systems, and energy storage, especially battery energy storage, can play a crucial role because of its inherent modularity and siting flexibility. Battery energy storage has thus expanded from its limited role as a load-leveling resource to serve in many other applications such as generation and transmission and distribution, and to ineet requirements on the customer's end of the utility network.

This analysis is a preliminary estimate of the impact of battery energy storage on a national scale based on the current understanding of its key benefits. Currently, there are limited data available on the value of these applications in the utility network. However, SNL, EPRI, and individual utilities are pursuing several studies that will further define and quantify their value in various utility scenarios. Results of these studies will enable future refinement of the estimates presented here, and revised versions of this study will be released as extensions of this preliminary report. Appendix I shows the outline and approach proposed for such a follow-on effort. It relies on a relatively detailed assessment, resulting in a higher degree of confidence and accuracy in the expected benefits.

This analysis and the future work planned to refine these estimates has been designated the "Gateway Benefits Study" to give this effort a unique identity.

\section{Approach/Information Sources}

The combined value of the benefits of battery energy storage for several utility applications on a national scale through the year 2010 were estimated in this "Gateway" Analysis. The benefits were obtained by examining utility operating and planning data reported to various regulatory and government agencies and using them to project the expected penetration of battery energy storage in the utility market. Potential savings to utilities through these applications of battery energy storage were compared to the cost of installing the battery systems, and a benefit-to-cosi ratio was calculated.

Several intormation sources were used in preparing the estimated cost/benefit figures. Utility generation expansion and transmission line addition data were obtained from the sources referenced in Appendix III. However, the distribution substation benefits could not be estimated because the necessary information is not reported by utilities to any agency in a consolidated form. Distribution substation planning information of the kind that is needed is generally available only from utilities on an individual basis. Efforts are being made to identify sources for obtaining this information, and it is expected that it will be available by the time the detailed follow-on assessment is undertaken in FY94. All assumptions, calculations and source data references used to support these estimates are contained in Appendix III.

The analysis is based on two important assumptions: (1) there are no changes in the regulatory climate of the investor-owned utilities and (2) distributed utility and integrated resource planning and evaluation have not had a major impact on utility planning practice, and traditional central station planning practice prevails. Deregulation of utilities, or a shift toward distributed utility or integrated resource planning, is not likely to change the estimate of absolute MW and MWh of battery systems installed, but it could have a significant impact on the rate and manner in which battery energy storage systems penetrate the utility energy storage market. If there is significant deregulation, then permitting, capital investment, and cost recovery of generation and transmission and distribution (T\&D) assets would receive different treatment than under the existing regulated environment. With a direct effect on asset utilization, battery energy storage could emerge as an attractive option in a deregulated climate, a situation that could change the rate at which battery energy storage systems are brought on-line.

The specific utility applications and the related benefits considered in this analysis are listed below. A detailed description of each application and the source of the benefit is given in Appendix II.

Generation Applications

- Spinning reserve

- Capacity deferral

- Generation dispatch

Transmission and Distribution Applications

- Transmission line deferral

- Distribution substation

Customer-side Applications

- Demand-side management 


\section{Findings}

The results of this analysis are summarized in Table I. These benefits are based on a cumulative market estimate of $11.33 \mathrm{GW}$ of battery storage by the year 2010. The total national benefit is $\$ 17.2$ billion by 2010. The corresponding estimate of the capital cost of the battery systems needed to capture this benefit is $\$ 9.06$ billion, which yields a benefit/cost ratio of 1.9 . An estimate of $\$ 800 / \mathrm{kW}$ was used for the battery system cost for the entire study period, and no cost reductions were assumed in the out years resulting from higher production volumes and/or introduction of advanced battery technologies with improved performance and lower cost in the late 1990s and early 2000 s.
Wide-scale implementation of resource planning concepts could impact how battery energy storage enters utility storage market. Both the distributed utility and the integrated resource planning concepts rely on small bundles of energy storage systems dispersed throughout the utility network to maximize asset utilization and facilitate the integration of distributed generation sources. Both methodologies favor smaller sizes of battery energy storage systems. Wider acceptance of these planning concepts may result in a large number of smaller sized battery energy systems being deployed by utilities, rather than the larger sizes preferred under central planning methodologies.

Table I. Estimate of Benefits by Application

Through 2010, in billions, 1993 \$

(Captured by installing $11.33 \mathrm{GW}$ of batteries at a cost of $\$ 9.06$ billion)

\begin{tabular}{lc|}
\hline \multicolumn{1}{c}{ Battery Energy Storage Application } & Benefit \\
\hline Generation & $\$ 10.3$ \\
Spinning Reserve & $\$ 3.3$ \\
Capacity Deferral & $\$ 5.7$ \\
Generation Dispatch & $\$ 1.3$ \\
Transmission and Distribution & $\$ 3.9$ \\
Transmission Line Deferral & $\$ 3.9$ \\
Distribution Substation & TBD \\
Customer-Side & $\$ 3.0$ \\
Demand-Side Management & $\$ 3.0$ \\
\hline Total Battery Energy Storage Benefits & $\$ 17.2$ \\
\hline Cost for Installing 11.33 GW of Battery Storage & $\$ 9.1$ \\
Benefit/Cost Ratio & 1.9 \\
\hline
\end{tabular}

- Distribution substation benefits could not be estimated because of a lack of source data at the time of the analysis. Benefits related to this application will be estimated in the follow-on study. 


\section{Appendix I: Outline for a Proposed Follow-on National Benefits/Market Study*}

\section{Objectives}

This two-phase study estimates the technical and financial benefits of battery energy storage to electric utilities at the national level. Phase I will focus on estimating the benefits of battery energy storage, and Phase II is a separate but related joint DOE-SNL/Industry supported market study that uses the findings of Phase I to estimate the size of the battery energy storage systems market in electric utility applications.

\section{Approach}

Phase I will be performed through the Utility Battery Storage Systems program at SNI and benefits of battery energy storage for one major region of the U.S. will be estimated within two to three months after the study starts. These estimates will quantify the economic benefits that could potentially be captured by electric utilities in one region of the U.S. through the widespread use of battery energy storage systems. The findings of the regional assessment will be extrapolated to estimate the impact of battery energy storage in the utility sector at the national level. The remaining section of this appendix details the proposed work plan and its salient features.

Phase II is an adjunct activity that utilizes the results of Phase I to estimate the size of the battery energy storage market for an extended study horizon comprised of several time windows. This information will be valuable for battery manufacturers and system suppliers to perform their business planning to meet the needs of this evolving market. It will also assist DOE in identifying specific program needs such that DOE support can be used effectively to accelerate the maturation of this market. It is proposed that Phase II be performed in partnership with an industry consortium made up of

* Draft proposal submitted by SNL to DOE/OEM: June 1993 utilities and battery system suppliers on a cost shared basis.

\section{Description and Discussion of Work Plan for Phase I: Benefits Study}

The Western Systems Coordinating Council (WSCC) is made up of 11 western states. The WSCC is one of nine regions recognized by the North American Electric Reliability Council (NERC) that make up the national utility network. The generation capacity installed in this region is approximately $150,000 \mathrm{MW}$, which represents $20 \%$ of the national capability. The WSCC also contains several major utilities such as PGE, SCE, and SMUD that are well informed about battery energy storage benefits and have conducted internal evaluations of this technology. PGE and SMUD are also likely to initiate battery projects in the near future.

Figure I-1 illustrates the major elements for Phase I of the study. The essence of this effort is to make two estimates of benefits for selected battery energy storage applications. One estimate is based on all relevant data reported by utilities to various regulatory and other agencies. These data include information on each utility regarding its current and future operations and are a good indicatur of the generation resources available to the utility, both at present and in the future. Utilities also report information of load growth, fuel mix, etc. Examination of this data base will be a means for estimating the benefits that the utilities could derive by the use of battery energy storage systems.

A second estimate of the same benefits will be made through information obtained during on-site interviews with each utility's planning staff. These interviews will not reference the estimates derived earlier through the data screening steps and will be an independent estimation by each utility's planning staff of the 


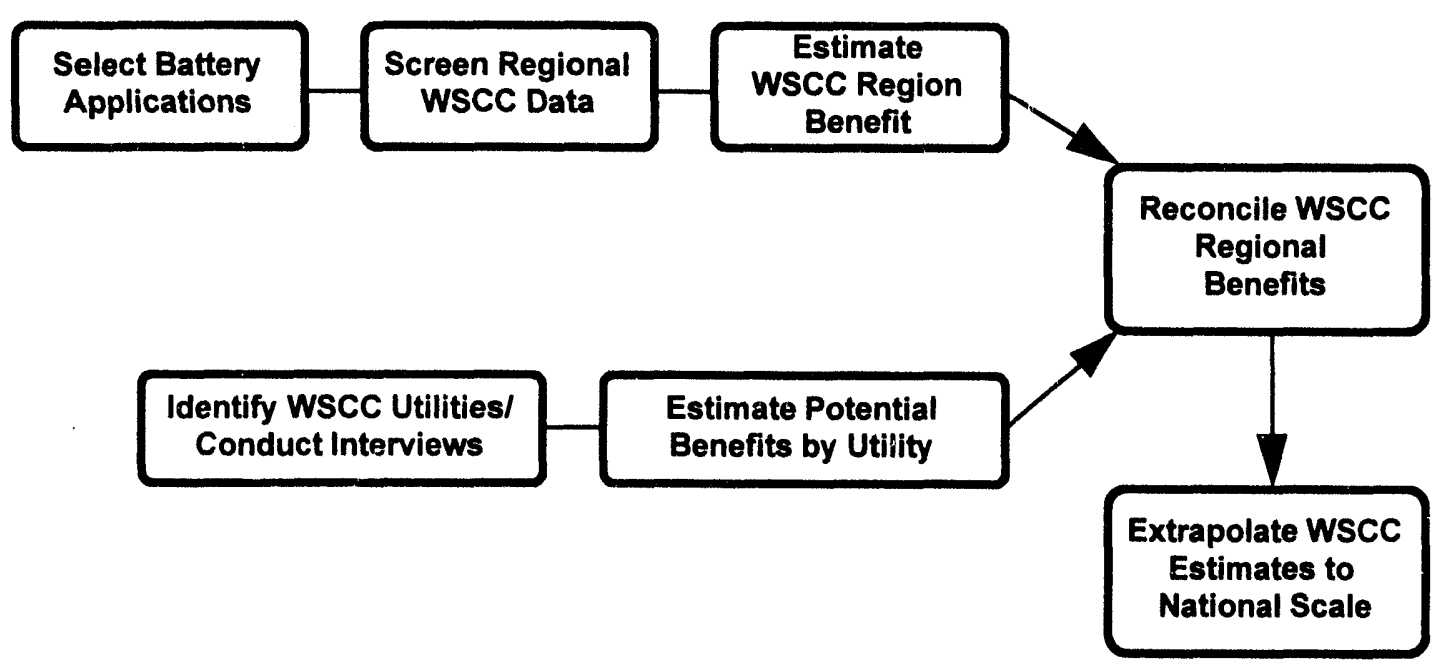

Figure 1-1. SNL Utility Battery Storage Systems Program. Phase I: National Benefits Study Work Plan.

potential benefits that their network could derive through the use of battery energy storage.

These two estimates will be reconciled, as shown in Figure 1-1, to provide a best estimate of the potential benefits of battery energy storage that may be available in the WSCC region. The WSCC estimates can be extrapolated to a national estimate through probabilistic analysis. There are several methodologies available for performing the probabilistic analysis segment of this study, including the use of synthetic utility models that are available from EPRI. These synthetic utility models were created and are naintained by EPRI to represent all the features of a typical utility in each reliability region. The use of these models may be a preferred option to estimate the national benefits after the WSCC benefits estimate is complete. A decision of the preferred methodology has not been made at this time for this probabilistic segment of the study and will be determined at a later date. 


\section{Appendix II: Discussion of Battery Energy Storage Applications and Benefits}

In the early 1980s, the concept of battery energy storage was based on the traditional role of storage in electric utility networks, that is, to reduce the utility's peak demand by discharging energy generated and stored during off-peak hours. The primary incentive for this mode of operation was to capture the differential in the cost of relatively inexpensive base-load generation and more expensive on-peak generation. Figure II-1 illustrates this with the typical summer and winter daily load profile from a representative utility whose generation resources include a mix of nuclear, coal, and oilfired units as well as pumped storage. The lower plot shows the load profile for January 2, 1985, where the load peaked about 10:00 AM at $2600 \mathrm{MW}$ and was supplied entirely by the baseload nuclear and coal units. The upper plot shows the load profile for a summer day (August 23, 1985). The load stayed above the 2600MW mark and required baseload as well as the intermediate oil-fired units. At about 12:00 noon, the utility used up its fossil-fuel generation sources and dispatched the pumped storage to meet the peak demand. This condition lasted until about 7:00 PM, and the pumped storage discharge was terminated and the system load requirements were met with the fossil-fuel generation units. During this peak period, the liility discharged approximately $1000 \mathrm{MWh}$ of stored energy over a seven-hour period to meet its system requirements.

This example is representative of the type of central storage capability needed to meet the load-leveling requirements of an average-sized utility with a peak summer load of about $4500 \mathrm{MW}$. Depending on load profiles, most utilities require storage capacities of four or more hours to perform any significant degree of load leveling, and pumped storage is the only conventional, commercial storage technology that can satisfy this requirement today. Typically, pumped storage units have power ratings of several hundred megawatts and storage capacities that range from 8 to 14 hours. But utilities have been constrained in utilizing pumped storage because of its severe environmental impact on land and water resources. Utilities recognize the economic advantages of large-scale storage but cannot utilize it because no existing technology can meet the requirements for such a system. Considering the long discharge time requirement, it was clear by the late 1980 s that existing lead-acid battery energy storage systems could not perform this function economically, and utilities showed little interest in utilizing this technology in this mode.

However, if the battery system size is reduced and no more than two to three hours of storage capacity are needed to meet a particular application's requirement, then battery systems could offer benefits that have economic value to the utility. In this size range, battery energy storage systems could also take advantage of their other distinguishing attributes, such as modularity, fast response, and a high degree of siting flexibility, that are not available with other generation or conventional storage technologies. By the late 1980s, utility applications that required smaller storage capacities had been identified, and there was a renewed interest in battery storage systems and in trying to quantify their benefits.

Specific types of battery energy storage applications and benefits that could be captured by relatively small-sized battery systems with one to three hours of storage capability were identified by four system studies conducted by the SNL Utility Battery Storage Systems program during FY 91 and 92 . These studies, along with studies conducted by EPRI, identified battery benefits in the generation, transmission, and end-use areas of the utility network as listed below:

- Generation benefits

- Spinning reserve

- Capacity deferral

- Generation dispatch

- Transmission \& Distribution benefits

- Transmission line deferral

- Distribution substation upgrade deferral

- Customer-side benefits

- Demand-side management 


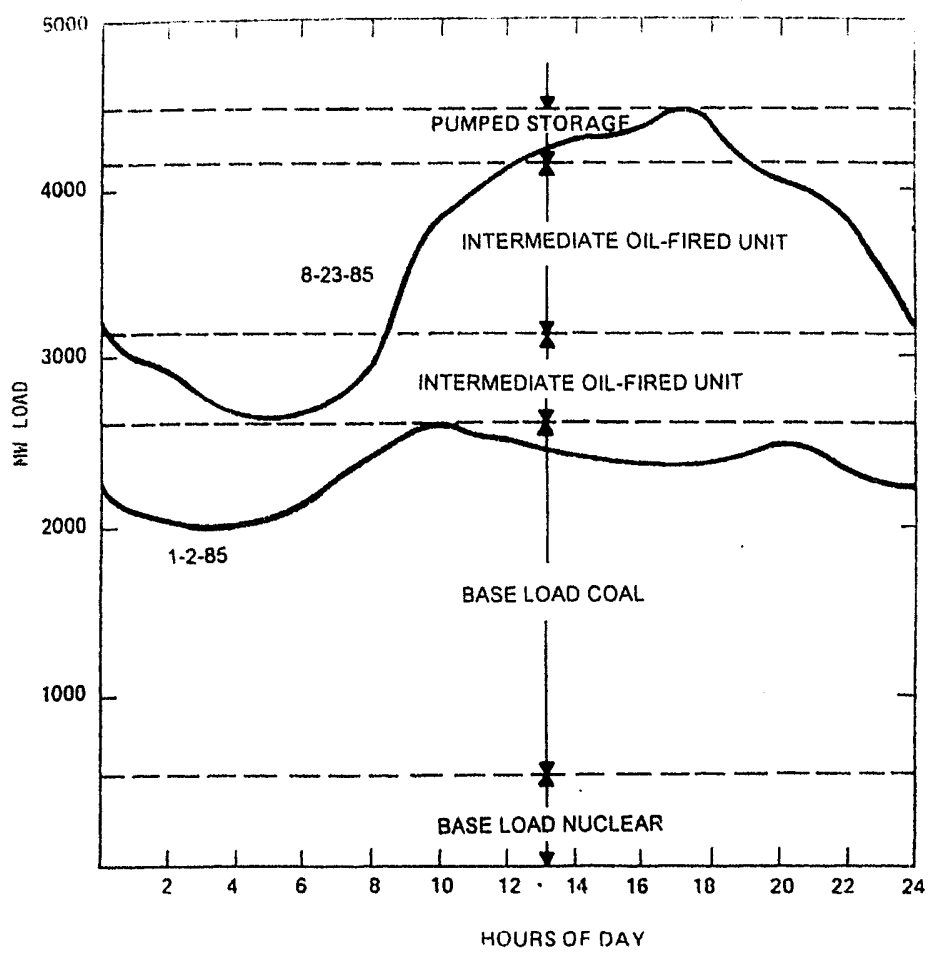

Figure I1-1. Typical Daily Load Profile for Winter and Summer and Generation Mix.

Each of these applications and their qualitative benefits are described in more detail in the remainder of this appendix.

\section{Spinning Reserve}

Utilities are required to hold a certain amount of generation capacity in reserve at all times to make up the capacity lost from the unscheduled outage of any generating unit. Typically, this requirement is met by operating fast response combustion turbines or backing down coal units to replace the lost capacity quickly until the system operator can take control measures and bring other generation on-line to make up the shortage. Battery energy storage can effectively displace the fossilfueled generating units operated in spinning reserve duty, thereby saving the cost of fossil fuel and freeing up the generation capacity otherwise set aside for spinning reserve.

Batteries systems used primarily for spinning reserve do not need high cycle life because events that typically generate the need for spinning reserve occur no more than one or two times a month on the utility network. When such an event occurs, the utility system operator needs less than 30 minutes to bring the system under control. Thus, spinning reserve is required only until the operator stabilizes the utility network, and battery energy systems for spinning reserve do not need more than 30 to 40 minutes of storage capability. The use of battery systems in this application has been demonstrated successfully by BEWAG, which is the electric utility that serves Berlin, Germany. BEWAG installed such a battery to provide frequency control and spinning reserve to the Berlin area when it was a divided city and electrically isolated from neighboring utility networks. Encouraged by the success of the BEWAG battery, the Puerto Rico Electric Power Authority purchased a 20MW/14-MWh battery system to perform the same function for their system. This battery will be operational in late 1993/early 1994.

\section{Capacity Deferral}

Capacity deferral is a benefit that can be claimed when a battery energy storage system defers the need for adding new generation capacity to meet the load growth in a utility network. Because of economies of scale and generation unit size availability, utilities can add new generation only in large increments of several hundred megawatts. Generation additions in these size increments usually have a low level of initial utilization until the utility system load grows. Battery storage systems 
are more modular and can be installed in much smaller incremental sizes that are more closely matched to the utility system load.

\section{Generation Dispatch}

At any given time, a utility typically operates sufficient number of generation units to satisfy the system load. However, because of inherent mismatches in aggregate $\mathrm{kW}$ capacity of the generation units and system load requirements, one or more of the operating units have to be operated at partial loads. Such a condition might persist for several hours every day until the system load grows and the partially loaded units can be ramped up to more efficient operating set points.

Under these conditions, battery energy storage can be used very effectively to decommit and/or more economically dispatch the otherwise partially loaded units, until the system load requirements more closely match the incremental output of the available generating units.

\section{Transmission Line Deferral}

Battery energy storage can be used to defer the construction of ne $w$ transmission lines to import more power into a service area by meeting load during peak hours. Utilities could potentially perceive battery energy storage as an attractive alternative to new transmission additions because the permitting process for new lines is becoming unacceptably long from delays caused by environmental concerns.

\section{Distribution Substation}

If a battery energy storage system is installed at a substation, it can effectively defer planned substation upgrades that would otherwise be necessary to meet new load growth in the substation service area. In this mode, the battery system can defer the transformer upgrade or, in some cases, the need to build a new substation. This application requires battery systems in the 2 to $3 \mathrm{MW}$ range, with storage capability of two or three hours.

This is a relatively new concept for using storage in the utility network because the traditional preconceptions of what a storage system should look like precluded the visualization of storage down at the substation level. Until now, substation planners in utility systems did not consider storage as a viable option in their planning scenarios. Today's lead-acid battery tech- nology makes it possible to package a self-contained storage system of 1 to $3 \mathrm{MW}$ and locate it within the boundary of an existing substation. Such a package also meshes well with the distributed utility planning and provides the hardware that can demonstrate its benefits in the near term.

Studies on substation feeder loads performed by Pacific Gas \& Electric show the economic viability of a storage system based on asset utilization within the utility network. Figure II-2 shows the load duration on approximately 3000 feeders in the PG\&E system. This figure shows that most substation feeders are loaded to their peak capacity for less than $10 \%$ of the time, or less than $\mathbf{8 7 0}$ hours per year. Since the system peak is the aggregate of individual feeder peaks, a storage device placed on those feeders with peaks that are coincident with the system peak could offer substantial benefits. In this application, the storage system not only defers the need for upgrading local substation facilities but indirectly also reduces the need for new peaking generation capacity at the system level. In this sense, the combined effect of all storage systems dispersed at the substations is to collectively perform a function equivalent to the original load leveling concept that has been the ultimate goal of battery energy storage application in utility networks.

As stated earlier, this is a new concept, and its benefits and the hardware that can perform this function are in the developmental stages. PG\&E has received proposals for the design and fabrication of prototype systems to demonstrate feasibility of the concept. It is expected that it will be built and fielded in late 1994 or early 1995 .

However, because of a lack of data on substation activity, the benefits associated with this application could not be estimated at this time. These benefits will be estimated in the more detailed assessment planned for the future.

\section{Demand-Side Management}

Battery energy storage systems can be installed at the customer site to reduce the $\mathrm{kW}$ peak and hence reduce the demand charges that are assessed based on the peak $\mathrm{kW}$ load. Industries with heavy machinery, or processes that create a sudden, sharp demand for electricity are suitable candidates for the installation of a battery energy storage system to reduce the peak. Battery systems that are less than $1 \mathrm{MW}$ in size, with a storage capability of one or two hours, can satisfy this application's requirements. 


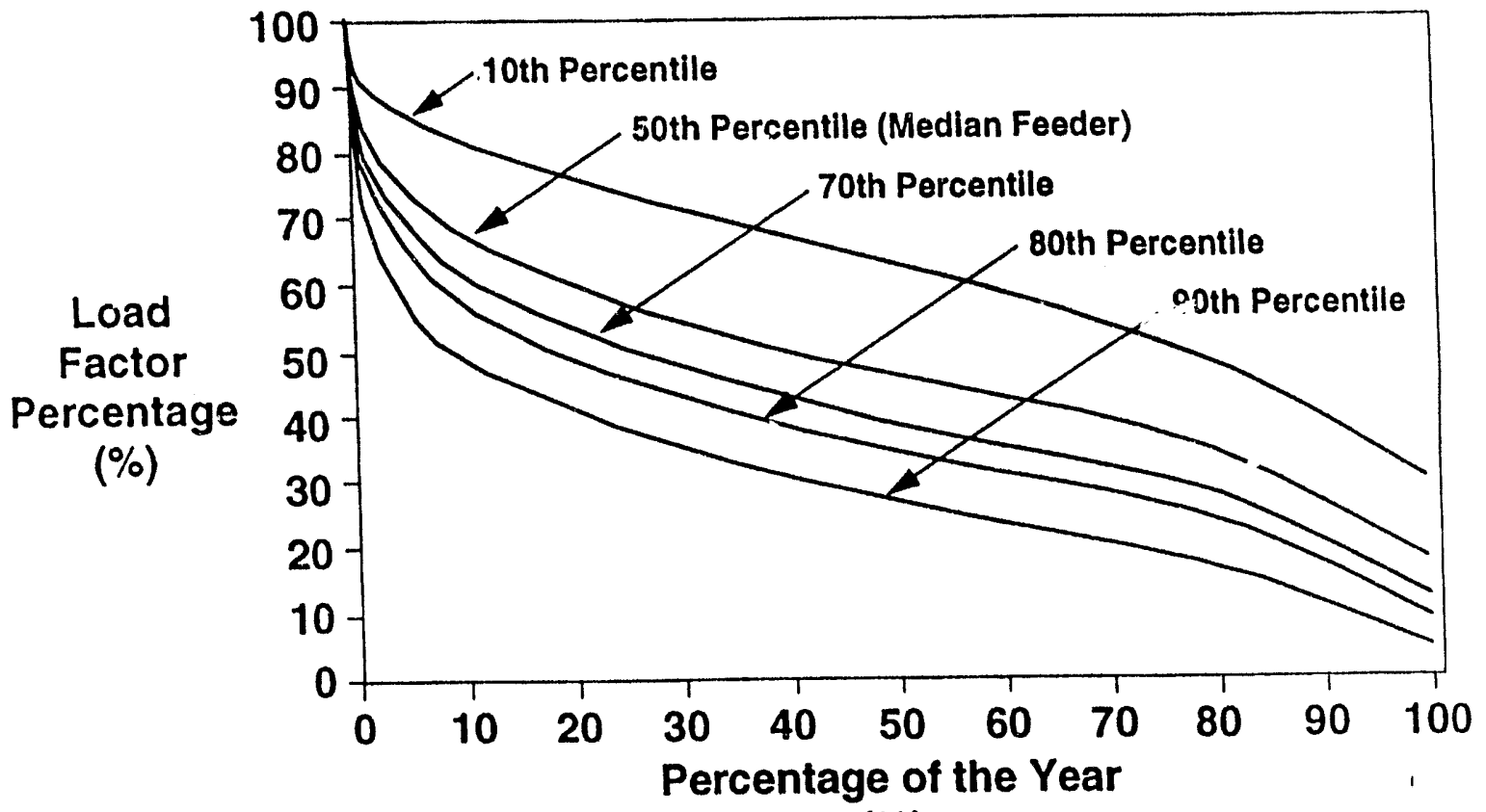

(\%)

Figure II-2. Feeder Load Duration Estimates ( 3000 feeders). 


\section{Appendix III: Assumptions, Calculations, and Source Data References}

\section{Market Calculation}

\section{Generation}

The generation capacity outlook for electric utilities is based on resource plans to meet growth in electricity demand. As competitive forces grow, so do the unrertainties and the array of options utilities will pursue. Among the options being considered are increasing output of existing plants; extending the lives of existing plants; increasing investment in demand-side management; purchasing power from nonutility generators; importing power from Canada and Mexico; and building new plants.

In terms of new construction, until the year 2000 , utilities will have excess capacity to serve baseload needs and will be adding gas-fired combined-cycle and combustion turbines to serve intermediate and peak needs. After 2000, baseload additions will be needed, while intermediate and peak plants will still account for a large portion of new additions.

As shown below, peak capacity will grow from 54.9 GW in 1995 to almost $80.1 \mathrm{GW}$ by 2010 . It is assumed that battery systems will defer $25 \%$ of the projected peaking capacity to the year 2000 , and $50 \%$ of this capacity through 2010 . This results in a potential market of $9.18 \mathrm{GW}$, as shown below.

|Reference: Table A.5 Electricity Generating Capability - DOE/EIA Annual Energy Outlook 199.3 - Combustion Turbine/Diesel (GW)]

\begin{tabular}{cc} 
Year & GW \\
\hline 1995 & 54.9 \\
2000 & 68.6 \\
2010 & 80.1
\end{tabular}

\author{
Peak Capacity Deferral Assumptions: \\ $25 \%$ from $1995-2000$ \\ $50 \%$ from $2000-2010$
Potential Market (GW):
$0.25(68.6-54.9)+0.50(80.1-68.6)$
$=3.43+5.75=9.18 \mathrm{GW}$ \\ Potential Market: \\ $9.18 \mathrm{GW}$ (approximately $1.2 \%$ of total installed \\ capacity)
}

\section{Demand-Side Management}

According to utility reports, the impacts of utilitysponsored demand-side management (DSM) programs have reduced peak demand by $25 \mathrm{GW}$ in 1990 and will reduce it by $56 \mathrm{GW}$ by the year 2000 , which accounts for approximately $10 \%$ of utility needs. DSM savings are projected in the National Energy Strategy (NES) to be 57 billion $\mathrm{kWh} / \mathrm{yr}$ in 2000 and 171 billion $\mathrm{kWh} / \mathrm{yr}$, by 2010 .

It is assumed that current trends in peak capacity reductions will continue through the year 2010 , and then DSM reductions will track the rate of growth for electricity demand at an average of $1.5 \%$ to $2 \%$ per year. The following table presents the capacity trends through 2010:

\begin{tabular}{llcc} 
Year & $\begin{array}{c}\text { Peak } \\
\text { Capacity } \\
\text { (GW) }\end{array}$ & $\begin{array}{c}\text { DSM } \\
\text { Savings } \\
\text { (GW) }\end{array}$ & $\begin{array}{c}\text { DSM } \\
\text { Savings } \\
(\%)\end{array}$ \\
\hline 1990 & 46.4 & 25 & 35.0 \\
2000 & 68.6 & 56 & 44.9 \\
2010 & 80.1 & $109^{*}$ & 57.6 \\
\hline - Extrapolated from 1990-2000 trends. &
\end{tabular}


The DSM market for battery storage can be estimated based on the following conservative assumptions: a market penetration of $1 \%$ in the year 2000 and $3 \%$ by the year 2010, which is based on the energy tripling from 2000 to 2010 . An estimated 53-GW peak reduction between 2000 and 2010 could be expected (109 GW $56 \mathrm{GW})$.

[Reference: Pg. 50 DOE/EIA Annual Energy Outlook 1993 - DSM Programs and Table A-23

DSM Savings Assumptions - NES Technical Annex, 2, 1991/1992.J

$$
\begin{aligned}
& \text { Potential Market }(\mathrm{GW}) \\
& =(56 \mathrm{GW} \times .01+53 \mathrm{GW} \times .03) \\
& =0.56 \mathrm{GW}(2000)+1.59 \mathrm{GW}(2010) \\
& =2.15 \mathrm{GW}
\end{aligned}
$$

\section{ESTIMATED TOTAL BATTERY MARKET} $=9.18+.2 .15=11.33 \mathrm{GW}$ by 2010

The total potential battery market is comprised of peak capacity deferral on the supply side and demandside savings on the customer side of the system. The market estimates are additive.

\section{Transmission Market}

Typically, an expansion of transmission facilities must accompany an expansion of generation if a system is to be adequate and reliable. Even when generating facilities are not added, transmission systems are modified from time to time to accommodate changes in the load. Strategic siting of battery systems such as at the end of a long line or dispersed in an urban load center can defer transmission expansion.

Generally, projected transmission additions are keeping pace with generation additions. The ratio of miles of transmission line ( $22 \mathrm{kV}$ and above) per megawatt of installed capacity has reached an asymptote of 0.857 . Also, the ratio of extra high voltage (EHV) transmission miles is approximately $11.56 \%$ of total transmission circuit miles.

The calculations below establish the basis of transmission line additions.

$$
\begin{aligned}
& \text { Ratio: Transmission Circuit Miles (22 kV } \\
& \text { and above to Installed Capacity (MW) } \\
& =0.857
\end{aligned}
$$

Ratio: EHV (254 kV and above) to Total Transmission ( $22 \mathrm{kV}$ and above) $=11.56 \%$
Year 2000: $\quad 0.857 \times 809,000 \mathrm{MW}$ installed $=693,313$ miles $(22 \mathrm{kV}+)$ $=80,147$ miles EHV
Year 2010: $0.857 \times 897,000 \mathrm{MW}$ installed $=768,729$ miles $(22 \mathrm{kV}+)$ $=88,865$ miles EHV

Difference $2000-2010=75,416$ miles, $22 \mathrm{kV}$ and above and 8,718 miles EHV (254 kV and above)

[Reference: $22 \mathrm{kV}$ and above: Chapter 5, Staff Report, Electric Power Supply and Demand for Contiguous US. 1989-1998, March 1990, US.

Department of Energy.]

\section{Benefits Calculation}

\section{Generation}

Studies involving production cost models indicate that batteries are often worth considerably more serving as spinning reserve rather than being cycled for supplying peak electricity.

As an alternative to using the battery as a charge/ discharge unit, a utility could use a battery only to provide spinning reserve with benefits that include shutting down the least efficient units and allowing generating units to operate at a higher load, thus reducing their average heat rates. The system total operating costs would be substantially lower.

Operating reserve criteria vary from utility to utility and NERC region to NERC region. Operating reserve policy generally consists of on-line MW spinning reserve requirements plus additional off-line quick start generation capable of responding within a specified time period (10 - 30 minutes). Spinning reserve typically includes unused MW capability of generators operating at partial load to cover sudden loss of generation.

Since batteries can be quickly started or changed from charging to discharging in the millisecond time frame, they can be used to supply the spinning reserve requirement. The potential benefit will depend on the type of generation used for spinning reserve. 
Potential economic benefits from battery storage systems are expected to include

- More efficient operation of units that would otherwise operate at partial load to provide spinning reserve and

- Cost savings from not running higher cost units that would otherwise have to operate to provide spinning reserve.

It is also expected that batteries used for this application would only have to operate until other generation units could be started or power purchased after sudden loss of a generating unit. Hence, batteries used for spinning reserve would probably not require large $\mathrm{MWh}$ storage capability.

Spinning Reserve: The benefit for spinning reserve is approximately $0.4 \%$ of total production cost.

\section{[Reference: Zaininger, "Benefits of Battery Storage as Spinning Reserve," EPRI-AP- 5327.]}

National Production Costs $=\$ 70$ B/year in 1990 .

[Reference: Financial Statistics for Selected Investor-Owned Electric Utilities, 1990, DOEJ EIA-0437.]

Annual Benefit: $0.4 \% \times 70 \mathrm{~B}=\$ 280 \mathrm{M} /$ year in $1990 \times(1.04)^{5}=\$ 340 \mathrm{M} /$ year in 1995 (assuming longterm inflation is $4 \%$.)

Present Value: $(6 \%, 1995-2010,15$ years $)=$ $\$ 340 \mathrm{M} \times 9.712=\$ 3.3 \mathrm{~B}$ (assuming $6 \%$ weighted average cost of capital as utility discount rate)

Spinning Reserve Benefits $=\$ 3.3$ billion

Capacity Deferral: Battery systems will displace 9.18 GW of peaking capacity by 2010 (Section 1.1). The capital cost of a peaking unit (combustion turbine) is about $\$ 500 / \mathrm{kW}$. The estimated benefit (cost deferral) is calculated below.

Capital cost of combustion turbine $=\$ 500 / \mathrm{kW}$ III-1)

Potential market $=11.33 \mathrm{GW}$ (from Generation, $\mathrm{p}$.

$$
\begin{aligned}
\text { Benefit } & =11.33 \mathrm{GW} \times 500 \$ / \mathrm{k} \\
& =\$ 5.665 \mathrm{~B} \approx \$ 5.7 \mathrm{~B}
\end{aligned}
$$

Capacity Deferral Benefit $=\$ 5.7$ billion
Generation Dispatch Benefits: In some utilities, there is a significant difference in incremental fuel costs during daily peak load periods and during minimum night loads. In addition, some utility systems, with large base-load units and a relatively low minimum load, experience difficulty in dispatching during morning load pick-up and off-peak hours. Economic dispatch, unit minimum load limits, and minimum down time requirements of base-load units cause this problem.

Batteries may be employed to dispatch the generation system and solve these daily dispatch problems more economically. For example, batteries may be discharged during daily peaks or ramped (from full charge to full discharge) at a higher rate during the morning load pick-up and ramped in the opposite direction during the evening load drop-off period. In addition, charging batteries at night can increase night generation levels and reducing daily cycling constraints.

Batteries may only require one to two hours of storage to relieve unit ramping constraints during morning pick-up and evening drop-off periods. However, several hours of energy storage are required to relieve daily generation unit cycling constraints.

Generation dispatch, including ramping and decommitment, is approximately $40 \%$ of spinning reserve benefit.

(References: SNL System Studies for Oglethorpe and San Diego Gas \& Electric; Zaininger, "Benefits of Battery Storage as Spinning

Reserve," EPRI AP-5327.)

Benefit: $40 \% \times \$ 3.3 \mathrm{~B}=\$ 1.3 \mathrm{~B}$

Generation Dispatch Benefit $=\$ 1.3$ billion

\section{Demand-Side Management}

From the customer perspective, the key benefits of battery DSM are monthly demand charge reductions and potential power quality improvements. Conservatively, focusing only on the demand charge savings, the estimated benefits are calculated as follows:

Typical Large Customer Demand Charge: $\$ 12 / \mathrm{kW}$ per month

[Reference: EPRI - AP/EM-5895.]

Potential Market: $2.15 \mathrm{GW}$ (from Demand-Side Management, p. III-2)

Annual Benefit: $2.15 \mathrm{GW} \times 12 \$ / \mathrm{kW}$ month $\times 12$ months $=\$ 309.6 \mathrm{M} / \mathrm{yr}$. 
Present Value: $\$ 309.6 \mathrm{M} / \mathrm{yr} . \times 9.712=\$ 3.007 \mathrm{~B} \approx$ $\$ 3.0 \mathrm{~B}(9.712$ is the present value factor for $6 \%$ discount rate, 15 years)

\section{Demand-Side Management Benefits $=\$ 3.0$ billion}

\section{Transmission Deferral (22 kV and Above)}

As discussed in the Transmission Market subsection, transmission line expansion tracks generation expansion in proportion to a fairly constant ratio (.857). Based on generation capacity deferrals shown there, transmission line deferrals are calculated. The expected benefits are based on half the transmission circuit miles, since battery systems would still require oneway transmission expansion (as opposed to a round-trip transmission circuit expansion).

$$
\begin{aligned}
1995-2000: & 3.43 \mathrm{GW} \times 0.857 \text { (ratio) } \\
= & 2,940 \text { miles } \\
& \text { Expected deferral of } 50 \% \\
& =1,470 \text { miles } \\
2000-2010: & 5.75 \mathrm{GW} \times 0.857 \text { (ratio) } \\
& =4,928 \text { miles } \\
& \text { Expected deferral of } 50 \% \\
& =2,464 \text { miles }
\end{aligned}
$$

Total deferral: $1,470+2,464=3,934$ miles $(22 \mathrm{kV}$ and above) $\$ 1 \mathrm{M}$.

Average cost of 1 mile of transmission is about

IReference: SNL System Studies for Oglethorpe, San Diego Gas \& Electric, EPRI Report GS-6687, Table 2-2.J

Benefit $=3,934$ miles $\times \$ 1 \mathrm{M} / \mathrm{mile}$

$$
=\$ 3.934 \mathrm{~B} \approx \$ 3.9 \mathrm{~B}
$$

Transmission Deferral Benefit $=\$ 3.9$ billion

\section{References}

Battelle-Columbus, "Load-Leveling Lead Acid Battery Systerns for Customer-side Applications-Market Potential and Commercialization Strategy," EPRIAP/EM-5895, July 1988, p. S-3.

Gjerde, A.R., Haas, S.M., Jabbour, S.J., et al., "Potential Benefit Storage to San Diego Gas and Electric-A Screening," prepared for Sandia National Laboratories and San Diego Gas \& Electric, Jan. 1992, Table 3.3, pp. 3-4.

Prabhakara, F.S., Clark, H.K., "An Estimate of Battery Energy Storage Benefits on the Oglethorpe Power System," prepared for Sandia National Laboratories and Oglethorpe Power Corp., PTI No. 147-92, Dec. 1992, p. 55.

U.S. Department of Energy, "National Energy Strategy, Technical Annex 2," 1991/1992, Table A-22, pg. 93, Table C-15, p. 127.

U.S. Department of Energy, "Staff Report, Electric Power Supply and Demand for the Contiguous United States, 1989-1998," March 1990, Chapter 5.

U.S. Department of Energy, "Annual Energy Outlook, 1993," DOE/EIA-0383(93), Jan. 1993, p. 50.

U.S. Department of Energy, "Financial Statistics of Selected Investor-Owned Electric Utilities, 1990," DOE/EIA-0437(90), Jan. 1992, Table 12, p. 26.

Zaininger, H.W., "Benefits of Battery Storage as Spinning Reserve: Quantitative Analysis," EPRI-AP5327, July 1987, Table S-1, p. S-2.

Zaininger, H.W., Clark, H.K., Brownell, G.C., "Potential Economic Benefits of Battery Storage to Electrical Transmission and Distribution Systems," prepared for EPRI, EPRI GS-6687, Jan. 9190, Table 2-2, p. 2-4. 


\section{Distribution}

ABB Power T\&D Co., Inc. (2)

630 Sentry Parkway

Blue Bell, PA 19422

Attn: P. Danfors

H. Weinrich

AC Battery Corporation

P.O. Box 325

East Troy, WI 53120

Attn: R. Flemming

Alaska Energy Authority

P.O. Box 190869

Anchorage, AK 99519-0869

Attn: D. Denig-Chakroff

American Electric Power Service Corp.

1 Riverside Plaza

Columbus, $\mathrm{OH} 43215$

Attn: C. Shih

Argonne National Laboratories (3)

CTD, Building 205

9700 South Cass Avenue

Argonne, IL 60439

Attn: C. Christianson

W. Deluca

K. Myles

Arizona Public Service

P.O. Box 5399

Phoenix, AZ 85072

Attn: R. Hobbs

AT\&T Energy Systems

3000 Skyline Drive

Mesquite, TX 75149

Attn: M. Bize

Bechtel

P.O. Box 193965

San Francisco, CA 94119-3965

Attn: W. Stolte
Bonneville Power Administration

Routing EO

P.O. Box 3621

Portland, OR 97208

Attn: J. Ray

C\&D Charter Power Systems, Inc. 3043 Walton Road

P.O. Box 239

Plymouth Meeting, PA 19462-0239

Attn: S. Misra

California State Air Resources Board

Research Division

P.O. Box 2815

Sacramento, CA 95812

Attn: J. Holmes

Chugach Electric Association, Inc.

P.O. Box 196300

Anchorage, AK 99519-6300

Attn: T. Lovas

Consolidated Edison (2)

4 Irving Place

New York, NY 10003

Attn: M. Lebow

N. Tai

Corn Belt Electric Cooperative

P.O. Box 816

Bloomington, IL 61702

Attn: R. Stack

Decision Focus, Inc.

650 Castro Street, Suite 300

Mountain View, CA 94041

Attn: S. Jabbour

Delco-Remy

7601 East 88th Place

Indianapolis, IN 46256

Attn: R. Rider 
Doug Danley

18131 Metz Dr.

Germantown, MD 20874

Eagle-Picher Industries

C \& Porter Street

Joplin, MO 64802

Attn: J. DeGruson

East Penn Manufacturing Co., Inc.

Deka Road

Lyon Station, PA 19536

Attn: M. Stanton

Electric Power Research Institute (6)

3412 Hillview Avenue

P. O. Box 10412

Palo Alto, CA 94303

Attn: J. Birk

S. Chapel

S. Eckroad

R. Schainker

P. Symons

R. Weaver

Electrotek Concepts, Inc.

P.O. Box $1654 i$

Chattanooga, TN 37416

Attn: H. Barnett

Eltech Research Corporation

625 East Street

Fairport Harbor, OH 44077

Attn: E. Rudd

Energetics, Inc. (5)

7164 Columbia Gateway Drive

Columbia, MD 21046

Attn: J. Badin

D. Baker

J. Hurwitch

C. Matzdorf

P. Taylor

Energy Systems Consulting

41 Springbrook Road

Livingston, NJ 07039

Attn: A. Pivec

Exxon Research Company

P.O. Box 536

1900 East Linden Avenue

Linden, NJ 07036

Attn: P. Grimes
Firing Circuits, Inc.

P.O. Box 2007

Norwalk, CT 06852-2007

Attn: J. Mills

General Electric Company (2)

Building 2, Room 605

1 River Road

Schenectady, NY 12345

Attn: E. Larson

D. Swann

General Electric Drive Systems

1501 Roanoke Blvd.

Salem, VA 24153

Attn: C. Romeo

Giner, Inc.

14 Spring Street

Waltham, MA 02254-9147

Attn: A. LaConti

GNB Industrial Battery Company (3)

Woodlake Corporate Park

829 Parkview Blvd.

Lombard, IL 60148-3249

Attn: S. Deshpande'

G. Hunt

J. Szymborski

Hawaii Electric Light Co.

P.O. Box 1027

Hilo, HI 96720

Attn: C. Nagata

Hughes Aircraft Company

P.O. Box 2999

Torrance, CA 90509-2999

Attn: R. Taenaka

Integrated Power Corp.

7524 Standish Place

Rockville, MD 20855

Attn: J. Adelman

IIZRO

P.O. Box 12036

Research Triangle Park, NC 27709

Attn: R. Nelson 
Johnson Controls Battery Group, Inc. (4)

5757 N. Green Bay Avenue

P. O. Box 591

Milwaukee, WI 53201

Attn: P. Eidler

R. Miles

T. Ruhlmann

W. Tiedeman

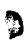

Johnson Controls Battery Group. Inc.

12500 W. Silver Spring Drive

P. O. Box 591

Milwaukee, WI 53201-0591

Attn: J. Zagrodnik

Lawrence Berkeley Laboratory (3)

University of California

One Cyclotron Road

Berkeley, CA 94720

Attn: E. Cairns

K. Kinoshita

F. McLarnon

Jo Meglen

P.O. Box 3232

Oakton, VA 22124

N.E.T.S.

P.O. Box 32584

Juneau, AK 99803

Attn: T. Neubauer

National Renewable Energy Laboratory (3)

1617 Cole Blvd.

Golden, CO 80401-3393

Attn: R. McConnell

J. Ohi

N. Rau

New York Power Authority

1633 Broadway

New York, NY 10019

Attn: B. Chezar

Northern States Power

414 Nicollet Mall

Minneapolis, MN 55401

Attn: M. Rogers

Oak Ridge National Laboratory

P.O. Box 2008

Oak Ridge, TN 37831

Attn: B. Hawsey, Bldg. 3025, MS-6040

J. Stoval, Bldg. 3147, MS-6070

J. VanCoevering, Bldg. 3147, MS-6070
Oglethorpe Power Company (2)

2100 E. Exchange Place

P.O. Box 1349

Tucker, GA 30085-1349

Attn: K. Scruggs

C. Ward

Oinnion Power Corporation (2)

P.O. Box 879

East Troy, WI 53120

Attn: H. Meyer

F. Ruf

Pacific Gas \& Electric (3)

3400 Crow Canyon Road

San Ramon, CA 94583

Attn: G. Ball

B. Norris

R. Winter

Pacific Northwest Laboratory (2)

Battelle Blvd.

Richland, WA 99352

Attn: J. DeSteese, K5-02

K. Drost

Power Technologies, Inc.

1482 Erie Blvd.

P.O. Box 1058

Schenectady, NY 12301

Attn: P. Prabhakara

Power Technologies, Inc.

775 Sunrise Ave.

Suite 210

Roseville, CA 95661

Attn: H. Clark

Puerto Rico Power Authority

G.P.O. Box 4267

San Juan, Puerto Rico 00936-426

Attn: W. Torres

R\&D Associates

2100 Washington Blvd.

Arlington, VA 22204-5706

Attn: J. Thompson

Robicon Corporation

100 Sagomore Hill Road

Pittsburgh, PA 15239

Attn: A. Maruschak 
Sacramento Nlunicipal Utility District

6201 S. Street

Sacramento, CA 95817

Attn: L. Wittrup

Salt River Project

MS PAB 357, Box 52025

Phoenix, AZ 85072-2025

Attn: H. Lundstrom

San Diego Gas \& Electric Company (2)

P.O. Box 1831

San Diego, CA 92112

Attn: T. Nelson

J. Wight

W. J. Schafer Associates

303 Lindbergh Avenue

Livermore, CA 94550-9551

Attn: S. Schoenung

R. K. Sen \& Associates 3808 Veazey Street NW

Washington, DC 20016

Attn: R. Sen

Silent Power, Inc.

163 West 1700 South

Salt Lake City, UT 84115

Attn: J. Rassmussen

Silent Power, Inc.

489 Devon Park Drive

Suite 315

Wayne, PA 19087

Attn: W. Auxer

Silent Power, Ltd.

Davy Road, Astmoor

Runcorn, Cheshire

UNITED KINGDOM WA7 1PZ

Attn: M. McNamee

Southern California Edison (2)

2244 Walnut Grove Avenue

P.O. Box 800

Rosemeade, CA 91770

Attn: A. Rodriguez

R. Scheffler

SRI International

333 Ravenswood Ave.

Menlo Park, CA 94025

Attn: C. Seitz
Stuart Kuritzky

347 Madison Avenue

New York, NY 10017

Superconductivity, Inc.

2114 Eagle Drive

Middleton, WI 53562

Attn: J. Emerick

United Engineers and Contractors

700 South Ash St.

P.O. Box 5888

Denver, CO 80217

Attn: A. Randall

University of Missouri - Rolla

112 Electrical Engineering Building

Rolla, MO 65401-0249

Attn: M. Anderson

University of Wisconsin - Madison

Dept. of Electrical \& Computer Eng.

1415 Johnson Drive

Madison, WI 53706

Attn: D. Divan

U.S. Department of Energy

Energy Information Administration

EI-531 FORSTL

Washington, DC 20585

Attn: T. Petersik

U.S. Department of Energy

Office of Energy Management

EE-14 FORSTL

Washington, DC 20585

Attn: M. Gunn

U.S. Department of Energy (21)

Office of Energy Management

EE-142 FORSTL

Washington, DC 20585

Attn: R. Eaton (20)

N. Rossmeissl

U.S. Department of Energy

Office of Propulsion Systems

EE-321 FORSTL

Washington, DC 20585

Attn: A. Landgrebe 
U.S. Department of Energy

Albuquerque Operations Office

Energy Technologies Division

Albuquerque, NM 87115

Attn: G. Buckingham

U.S. Windpower, Inc.

6952 Preston Avenue

Livermore, CA 94.550

Attn: B. Erdm?n

Westinghouse STC

1310 Beulah Fioad

Pittsburgh, Pt. 15235

Attn: H. Seunders

iv. R. Grace \& Compañy

62 Whittemore Avenue

Cambridge, MA 02140

Attn: S. Strzempko

Yuasa-Exide

P.O. Box 14205

Reading, PA 19612-4205

Attn: F. Tarantino

Zaininger Engineering $\mathrm{Co}$., Inc. 1590 Oakland Road, Suite B211

San Jose, CA 95:31

Attn: H. Zaininger
2000 H. Schmitt

2200 R. Bair

2206 R. Clark

2206 L. Lachenmeyer

2222 K. Grothaus

2223 D. Doughty

2225 P. Butler (10)

2225 A. Akhil

2225 J. Braithwaite

2225 N. Clark

2225 J. Freese

2225 R. Jungst

2225 S. Klassen

10214 J. Kerr, Attn: D. Wilt

6200 D. Arvizu

6213 T. Bickel

6218 W. Bower

6218 R. Bonn

8111 P. Falcone

8300 W. McLean

8523-2 Central Technical Files

7141 Technical Liôrary (5)

7151 Technical Publications

7613-2 Document Processing for DOE/OSTI (10) 
$Y$
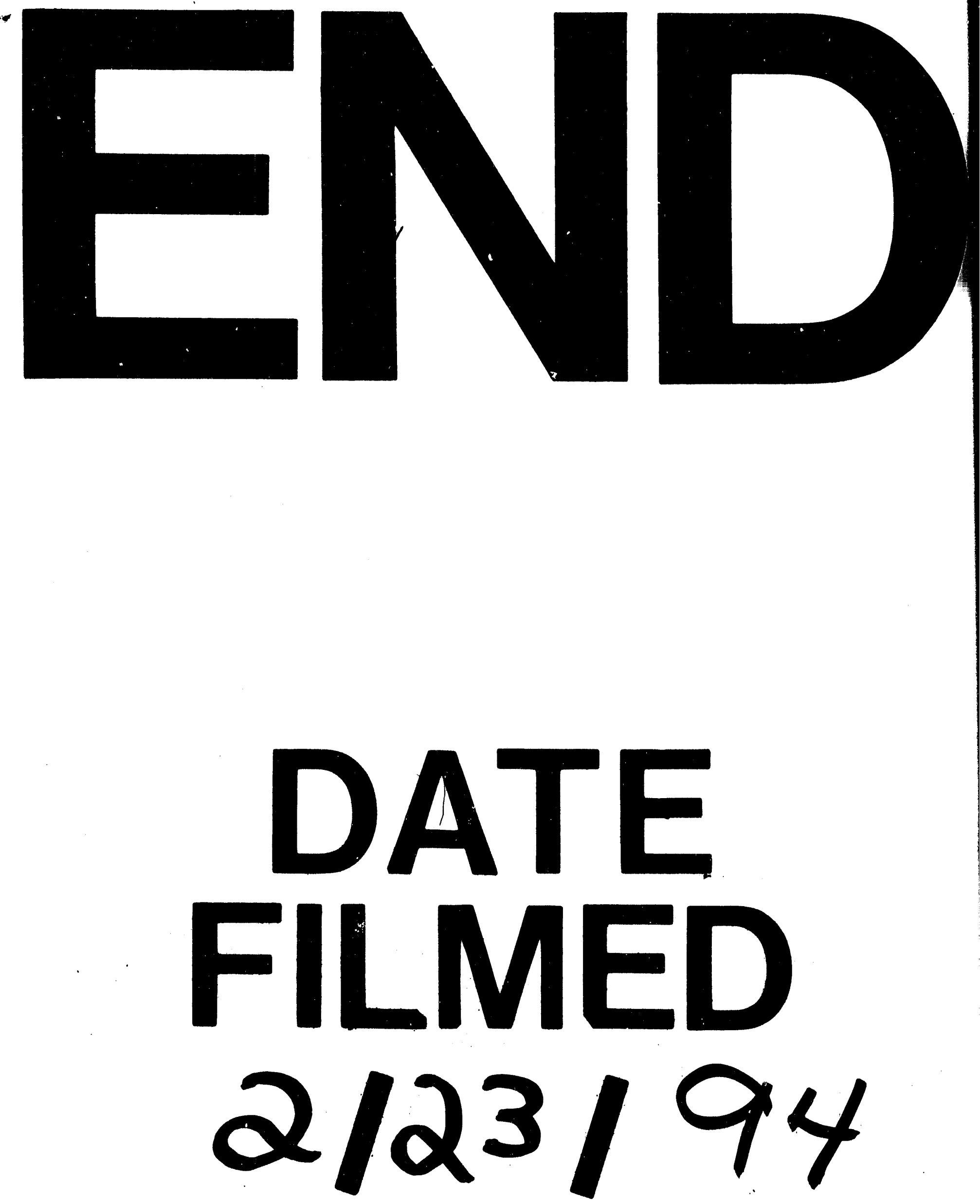

1 
